GEOLOGICA BALCANICA, 48 (1), Sofia, April 2019, pp. 43-61.

\title{
An assessment of potential groundwater recharge zones in Bulgaria
}

\section{Tanya Vasileva}

Geological Institute, Bulgarian Academy of Sciences, Acad. G. Bonchev Str., Bl. 24, 1113 Sofia, Bulgaria; e-mail: tanyav@geology.bas.bg

(Accepted in revised form: March 2019)

\begin{abstract}
Groundwater resources on the territory of Bulgaria are unevenly distributed in both spatial and temporal aspects. The effective usage of these valuable assets is of paramount importance, since any overexploitation would eventually lead to their depletion. Remote sensing data and satellite images have increasingly been used in groundwater exploration and management. An integrated approach was applied in the present study in order to delineate potential groundwater recharge zones on the territory of Bulgaria. Data from various sources were used to prepare different thematic layers. These layers were then transformed into raster data of $1 \times 1 \mathrm{~km}$. Lineament and drainage density maps of the research area were made with the help of GIS technology. In addition, a map was made for the annual total precipitation for the period from 1931 to 1985. DEM (Digital Elevation Model) data on a global scale at $90 \mathrm{~m}$ horizontal resolution were used for the slope analysis. A groundwater potential map was produced, which integrates several thematic maps, such as annual rainfall, geology, lineament density, land use, slope, soils, and drainage density. The thematic maps were then converted into a raster graphic format in order to be easily integrated into a GIS platform. The raster maps of these factors were then allocated a fixed score and weight-computed. The weights of those factors contributing to the groundwater recharge were derived by using the following components: geological map, lineament-length density map, land cover data base, soil data base, drainage-length density map, and slope gradient map. Subjective weights were assigned to the respective thematic layers, and they were overlaid in a GIS platform for the identification of potential groundwater recharge zones within the study area. These potential recharge zones were then categorized as being very good, good, moderate, poor, and very poor.
\end{abstract}

Vasileva, T. 2019. An assessment of potential groundwater recharge zones in Bulgaria. Geologica Balcanica 48 (1), 43-61.

Keywords: groundwater, potential recharge zones, Bulgaria, SRTM, GIS.

\section{INTRODUCTION}

Factors with major influence on potential zones for groundwater recharge can be divided into two main groups: climatic factors and land area factors. Among the climatic factors, the precipitation may be emphasized above all. The land area factors include the region's topography, hydrographic network, lithology, lineament patterns, type of soils, and land use/cover. Correct determination of the zones of potential groundwater recharge is of paramount importance since these are not only the areas where natural resources are replenished, but they are the areas where it is easier for pollutants to be infiltrated into aquifers of most active water exchange. In case of contamination of the surface and presence of recharge potential, this contami- nation may penetrate through the vadose zone and reach the groundwater. The purpose of this study is to determine the boundaries of potential zones of groundwater recharge on the territory of Bulgaria based on the influence of morphometric parameters, such as slope gradient and horizontal fragmentation (or drainage-length density), lithological settings and lineament-length density, total sum of annual mean rainfall, soil texture, and land cover.

The elaboration of a methodology to delineate the potential groundwater recharge zones requires a thorough knowledge of the processes affecting recharge. The methodology described herein aims at clarifying the sequence until the final estimate of potential groundwater recharge zones can be reached. This is important, since the assessment generally involves a combination of several processes or a 
succession of interconnected influencing factors of a certain feature of the area's hydro-environment.

Delineating the potential recharge zones has been carried out in many countries, and various methods have been used so far (Krishnamurthy et al., 1996; Saraf and Choudhury, 1998; Shahid et al., 2000; Jaiswal et al., 2003; Sener et al., 2005; Shaban et al., 2006; Yeh et al., 2009; Chenini et al., 2010; Kadam et al., 2015). For the territory of Bulgaria, such an assessment has not been undertaken yet. Therefore, in the present study, a summary of all available free-access information on the subject of recharge potential zones has been attempted, and an up-to-date methodology for making such an assessment is presented.

A GIS-model was employed in order to delineate the potential groundwater recharge zones of Bulgaria. Identifying suitable sites for the recharge was conducted through a knowledge-based factor analysis, making use of layers describing the precipitation, lithology, lineaments, slope gradient, land cover, soil types, and drainage features of the studied area.

\section{STUDY AREA - TOPORGAPHY, GEOLOGY, SOIL COVER AND CLIMATE}

The delineation of the zones of potential groundwater recharge on the territory of Bulgaria was carried out with respect to the relevant topographic features (Fig. 1), making use of GIS technology. Bulgaria is almost $111,000 \mathrm{~km}^{2}$ in area, having a very complex geological structure, and widespread existence of varied rock formations with ages from the Quaternary to the Precambrian. Quaternary deposits (de-

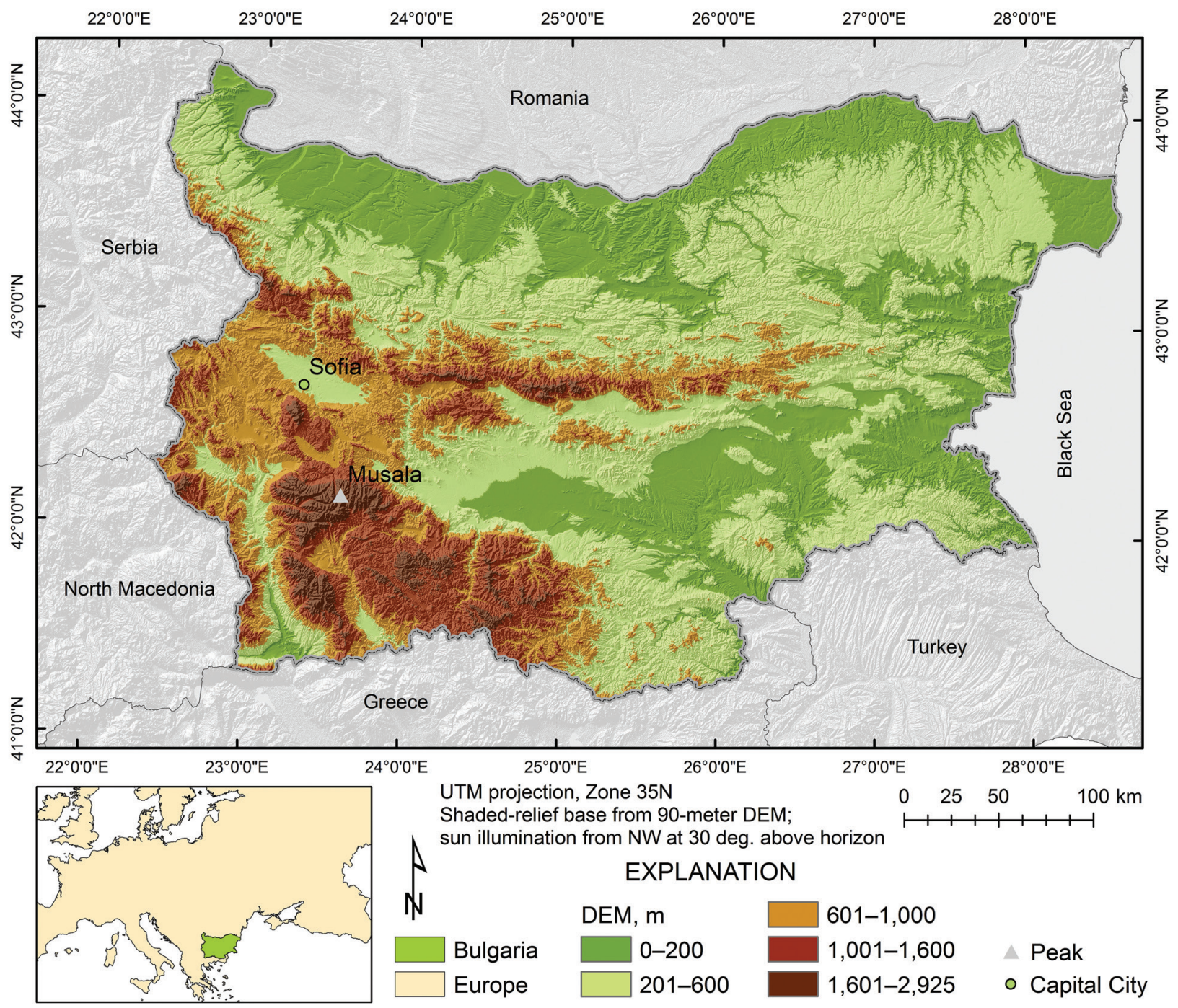

Fig. 1. Location of the study area and a topographic map of Bulgaria. 
luvial, eolian, and alluvial) occupy almost the entire northern part of the country, where loess cover is also widespread. The depth of loess deposits is about $40-50 \mathrm{~m}$ in close proximity to the Danube River and, south to the Fore-Balkan, its thickness is reduced to about 3-5 m (Minkov, 1968). According to their genesis, pre-Quaternary rocks in Bulgaria are magmatic (intrusive, effusive and pyroclastic), sedimentary, and metamorphic (Fig. 2). Their variable lithological compositions have led to the formation of porous, karst, fissured-karst, fissured and fissured-porous aquifers (Antonov et al., 1960), which may be described as having very high, high, moderate, low, and poor water-holding capacity (Kamenov et al., 1963b).

The topography of Bulgaria is quite varied, consisting of high and low terrains that generally ex- tend from the east to the west across the country. The average altitude is approximately $470 \mathrm{~m}$, and the country's relief is characterized by the existence of lowlands in its northern part and heavily dissected mountainous and semi-mountainous areas in the south (Fig. 1). Most terrains on high elevations are located in the south-western part of the country, where Peak Musala, the highest point in the Rila Mountains and the Balkan Peninsula, rises to 2,925 m above sea level. The country is characterized by predominantly flattish and hilly areas, with altitude varying between $0 \mathrm{~m}$ and $600 \mathrm{~m}$, and such areas cover about $72 \%$ of its territory.

As to the existing soil cover, the most widely spread types of soils in northern Bulgaria are the chernozems and luvisols. On the other hand, in the southern part of the country, a wide variety of soil

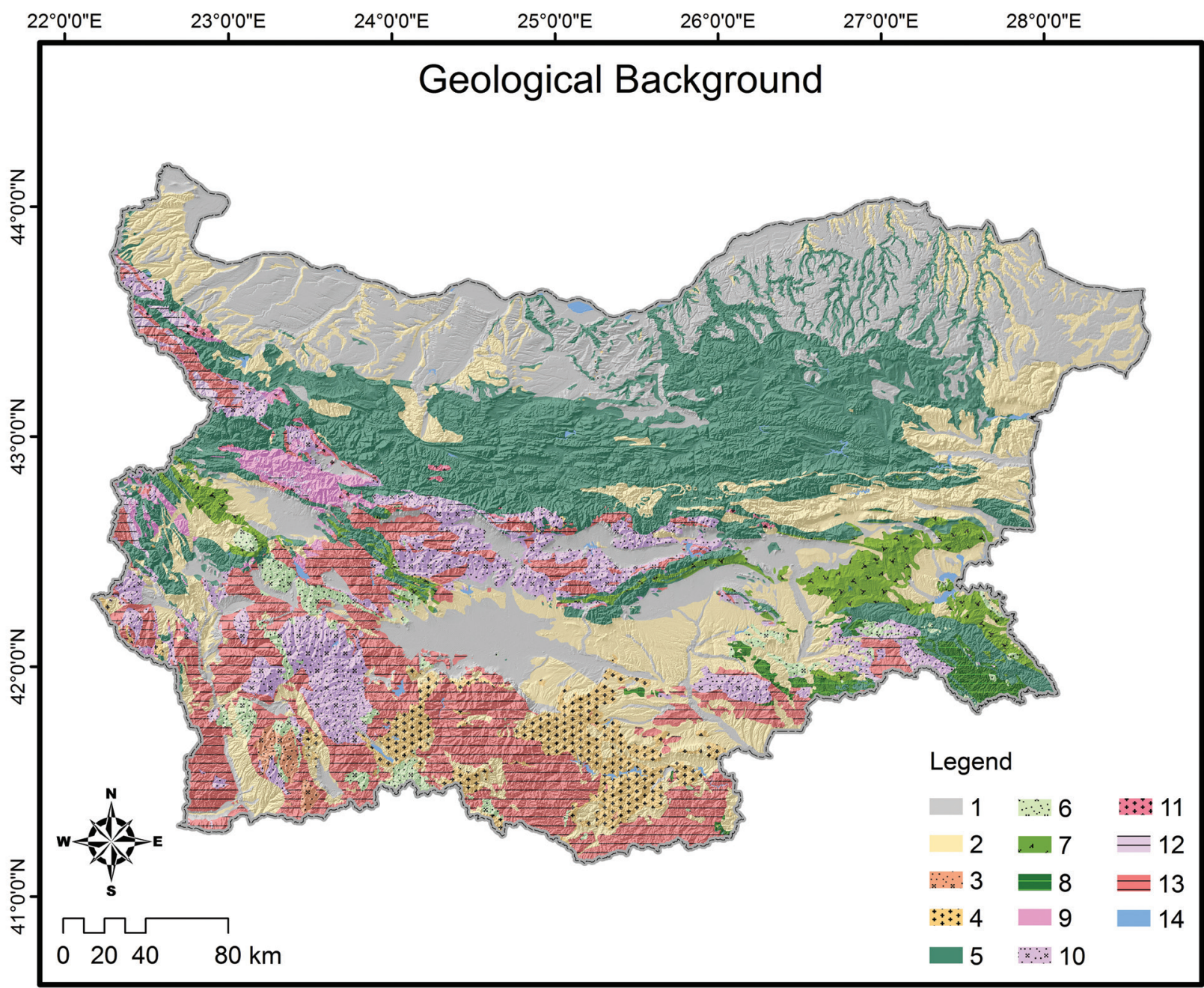

Fig. 2. Geological map of Bulgaria showing the main types of rocks (after Cheshitev and Kanchev, 1989). Legend: 1 - Quaternary sediments; 2 - Neozoic sedimentary rocks; 3 - Neozoic intrusive rocks; 4 - Neozoic volcanic and volcano-sedimentary rocks; 5 - Mesozoic sedimentary rocks; 6 - Mesozoic intrusive rocks; 7 - Mesozoic volcanic and volcano-sedimentary rocks; 8 - Mesozoic metamorphic rocks; 9 - Paleozoic sedimentary rocks; 10 - Paleozoic intrusive rocks; 11 - Paleozoic volcanic and volcanosedimentary rocks; 12 - Paleozoic metamorphic rocks; 13 - Precambrian metamorphic rocks; 14 - water. 
types can be found, such as cinnamonic soils, smolnitza, leptosols, alisols (zheltozem podzolic soils), as well as soils having visible relict and identity with soils from areas in northern Bulgaria: chromic luvisols, nitisols, etc. Much of Bulgaria's territory is covered with shallow soil types (leptosols), which are widespread all over the country (Ninov, 1997, 2002).

The climate in Bulgaria is moderately continental, with maximum precipitation in May and June and minimum in February. In the southernmost part of the country, the climate is continentally Mediterranean, with maximum precipitation in the fall and winter seasons and extensive droughts in the summer. The yearly distribution of rainfalls can be described as uneven in time (Fig. 3). The average total sum varies in the range between $500 \mathrm{~mm}$ and $550 \mathrm{~mm}$, and from $600-700 \mathrm{~mm}$ in the plains to $1,000-1,400 \mathrm{~mm}$ in the higher mountainous areas (Koleva and Peneva, 1990). The least amounts of precipitation have been measured along the Black Sea coast - from $450 \mathrm{~mm}$ to $500 \mathrm{~mm}$. During the winter months, it often snows at places of high altitudes. The average maximum yearly air temperature is $+14{ }^{\circ} \mathrm{C}$, and the minimal is $-3^{\circ} \mathrm{C}$ (Kyuchukova, 1983). The maximum temperatures have been recorded in July and August, and the minimum ones in January.

\section{DATA AND METHODOLOGY}

In order to assess the potential groundwater recharge zones of Bulgaria, a modern approach was attempted, making use of data integration and processing in GIS environment. The zones were delineated according to the influence of the following factors: precipitation, geological and hydrogeological settings, lineaments, land cover, slope gradient, drainage, and types of soil. GIS technology was also

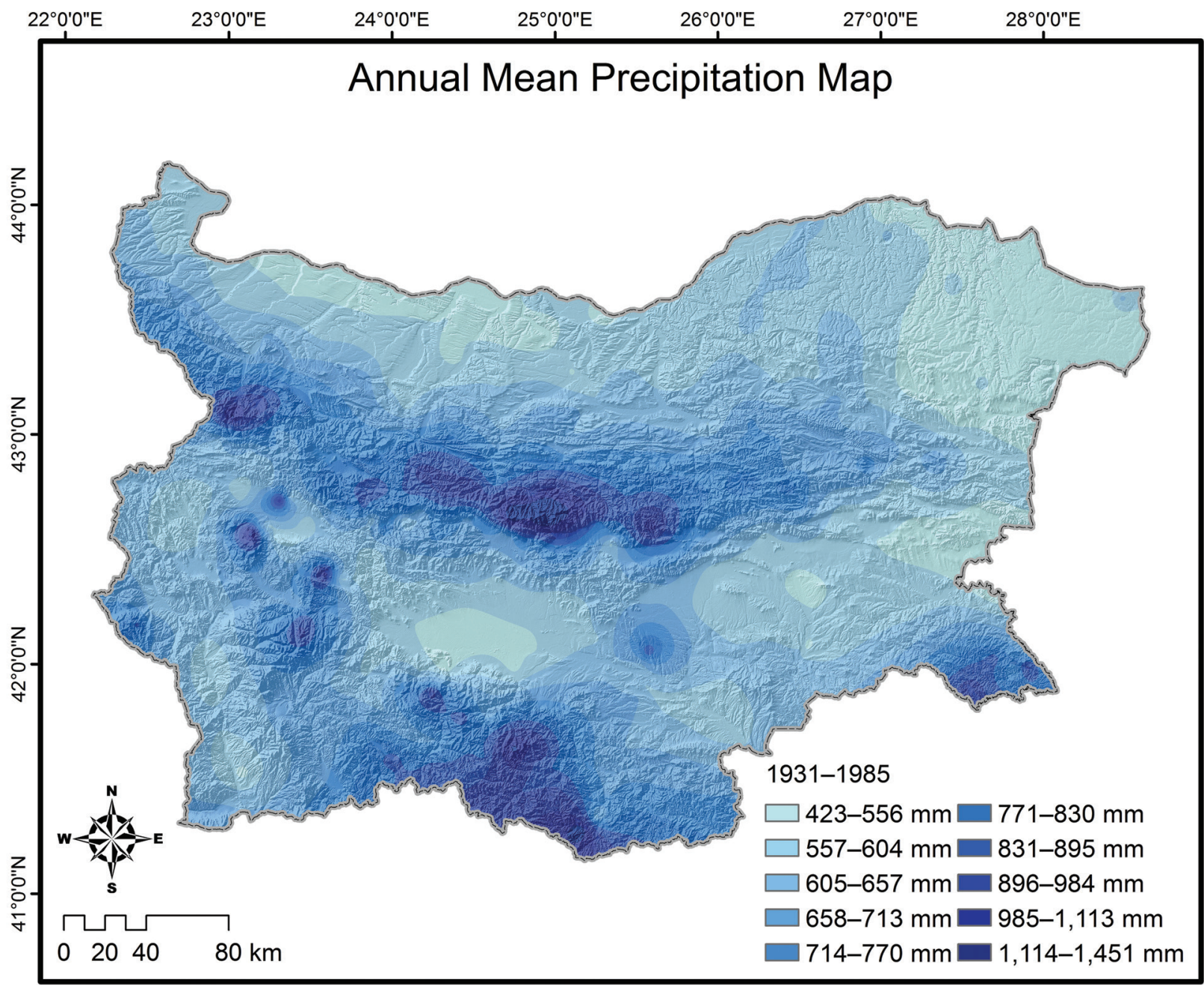

Fig. 3. Annual mean precipitation in Bulgaria for the period 1931-1985 (data from Koleva and Peneva, 1990). 
used in order to determine the horizontal fragmentation, lineament density, and areal-extent rainfall for the study area.

In the process, several subsequent steps were applied accordingly. Initially, the problem was reviewed in the relevant literature (Sener et al., 2005; Shaban, et al., 2006; Yeh et al., 2009; Magesh et al., 2012; Murasingh and Jha, 2013; Gumma and Pavelic, 2013; Venkateswaran et al., 2014; Selvam et al., 2016; Senanayake et al., 2016; Yeh et al., 2016; etc.). After that, data were collected, processed, and digitalized, when necessary. Finally, spatial analyses (i.e., weighting of each factor pertaining to the potential recharge areas) were carried out, and the outputs were categorized.

\section{Data}

Abundant data from various sources have been processed in the study, such as meteorology, soils, topography, land use, river drainage patterns, geological, hydrogeological, and lineament patterns.

The climatic data include mean annual total sum of the precipitation for the period of 1931-1985, measured at 284 stations unevenly distributed all across the territory of Bulgaria (see Koleva and Peneva, 1990). After the integration of all precipitation data into GIS, and using interpolation techniques, a map of the average annual rainfall was generated in a $1 \times 1 \mathrm{~km}$ grid (Fig. 3 ).

As far as soils are concerned, data for their texture in the one-meter surface layer were used. When there is a difference between the top soil $(0.3 \mathrm{~m}$ in depth) and the subsoil $(0.7 \mathrm{~m})$, the value less favorable for the recharge was used. Data was provided by the European Soil Data Centre (ESDB v2.0. 2004). They were prepared for usage by the Land Resource Management Unit of the Institute for Environment and Sustainability at the Joint Research Centre (JRC) of the European Commission, located in Ispra, Italy.

For the topographic analysis (Fig. 1), Shuttle Radar Topography Mission (SRTM) Digital Elevation Model (DEM) data on a global scale at $90 \mathrm{~m}$ horizontal resolution (http://srtm.csi.cgiar.org/) were used in order to produce a slope gradient map. The slope of the terrain plays a major role in determining the recharge potential zones, i.e., at steeper slopes more surface runoff is generated and on flatter terrains larger amounts of the precipitation are infiltrated into the ground. About 52\% of the land area of Bulgaria is characterized by slopes of less than $4^{\circ}$, thus facilitating slow surface runoff, and only about $3 \%$ is characterized by slopes of $>26^{\circ}$, which facilitates a more rapid surface runoff.
Both surface runoff and infiltration depend on the existence of forested areas on the terrain. The data utilized for the land cover were obtained from CORINE Land Cover 2006 Project (CLC 2006). The polygon data can be freely accessed at the website of the Executive Environment Agency of Bulgaria (http://eea.government.bg/bg/projects/korine-14/osn-inform). The basic information for the project comes from satellite images. Information for the land cover was interpretable from satellite images, as well as the land use maps. The CORINE Land Cover 2006 Project forms part of the pan-European CORINE Land Cover Project, developed by the European Environment Agency (https://www. eea.europa.eu/data-and-maps/data/clc-2006-vectordata-version-2).

The horizontal fragmentation map was compiled by using drainage features data. The river network was digitalized within the framework of JICA Project (2006-2008), with data collected from topographic maps of Bulgaria in scale 1:100 000.

The demarcation of geological formations was obtained from the geological map of Bulgaria, in which only the major geological formations are presented. The map was prepared by the Committee of Geology of Bulgaria in scale 1:500 000 (Cheshitev and Kanchev, 1989) and vectorized within the framework of JICA Project (2006-2008). The lineaments in the studied area were determined from the geological series maps of Bulgaria in scale 1:100 000. Subsequently, a lineament-length density map in a raster graphic format was prepared in GIS environment.

All data used in the present study can be seen in Table 1. This information was used in a digital format for the preparation of various thematic layers.

\section{Methodology}

The methodology developed below aims at determining the recharge potential and consists of four stages. Initially, the problem was investigated, the necessary data were collected, and a database was created. Thematic layers related to the recharge potential were identified. The second stage involved processing of the layers to ensure uniform projection in UTM (zone 35N, datum WGS84), assigning the relevant scores and weightages. During the third stage, the thematic layers were converted into raster images and integrated with their weightages in GIS environment. During the fourth (final) stage, the outputs were categorized into the following five classes: very good, good, moderate, poor, and very poor. The methodology followed in the process of research is shown in Fig. 4. 
Table 1

Data layers used in this study

\begin{tabular}{|c|c|c|}
\hline Layers & Data obtained from / Description & Source \\
\hline $\begin{array}{l}\text { Lineament } \\
\text { patterns }\end{array}$ & - & Geological Series Maps 1:100 000 \\
\hline Land cover & $\begin{array}{l}\text { Executive Environment Agency of Bulgaria, Land Cover } \\
2006 \text { Project }\end{array}$ & $\begin{array}{l}\text { Database CORINE of the European } \\
\text { Environment Agency }\end{array}$ \\
\hline \multirow[t]{4}{*}{$\begin{array}{l}\text { Geology } \\
\text { (Lithology) }\end{array}$} & JICA Project (2006-2008) & $\begin{array}{l}\text { Cheshitev, G., Kanchev, I. (1989) } \\
\text { Geological map of Bulgaria 1:500 } 000\end{array}$ \\
\hline & $\begin{array}{l}\text { Map of hydrogeological elements, important for construc- } \\
\text { tion work 1:500 } 000\end{array}$ & Kamenov et al. (1963b) \\
\hline & Engineering-geological map of Bulgaria 1:500 000 & Kamenov et al. (1963a) \\
\hline & $\begin{array}{l}\text { Map of the hydrogeological division of Bulgaria 1:600 } 000 \\
\text { (1960) }\end{array}$ & Antonov et al. (1960) \\
\hline $\begin{array}{l}\text { Drainage } \\
\text { network }\end{array}$ & JICA Project (2006-2008) & Topographic Series Maps 1:100 000 \\
\hline Slope & Digital Elevation Model (DEM) 90 m & http://srtm.csi.cgiar.org \\
\hline Precipitation & $\begin{array}{l}\text { Meteorological station / Precipitation Map was generated by } \\
\text { employing interpolation techniques on a GIS platform }\end{array}$ & Koleva and Peneva (1990) \\
\hline Soils & $\begin{array}{l}\text { ESDB ver2.0. 2004. The European Soil Database } \\
\text { distribution }\end{array}$ & $\begin{array}{l}\text { Joint Research Center, European } \\
\text { Commission }\end{array}$ \\
\hline
\end{tabular}

\begin{tabular}{|l|}
\hline Geology \\
Lineaments \\
Land cover/use \\
Slope \\
Drainage \\
Precipitation \\
Soils \\
\hline
\end{tabular}

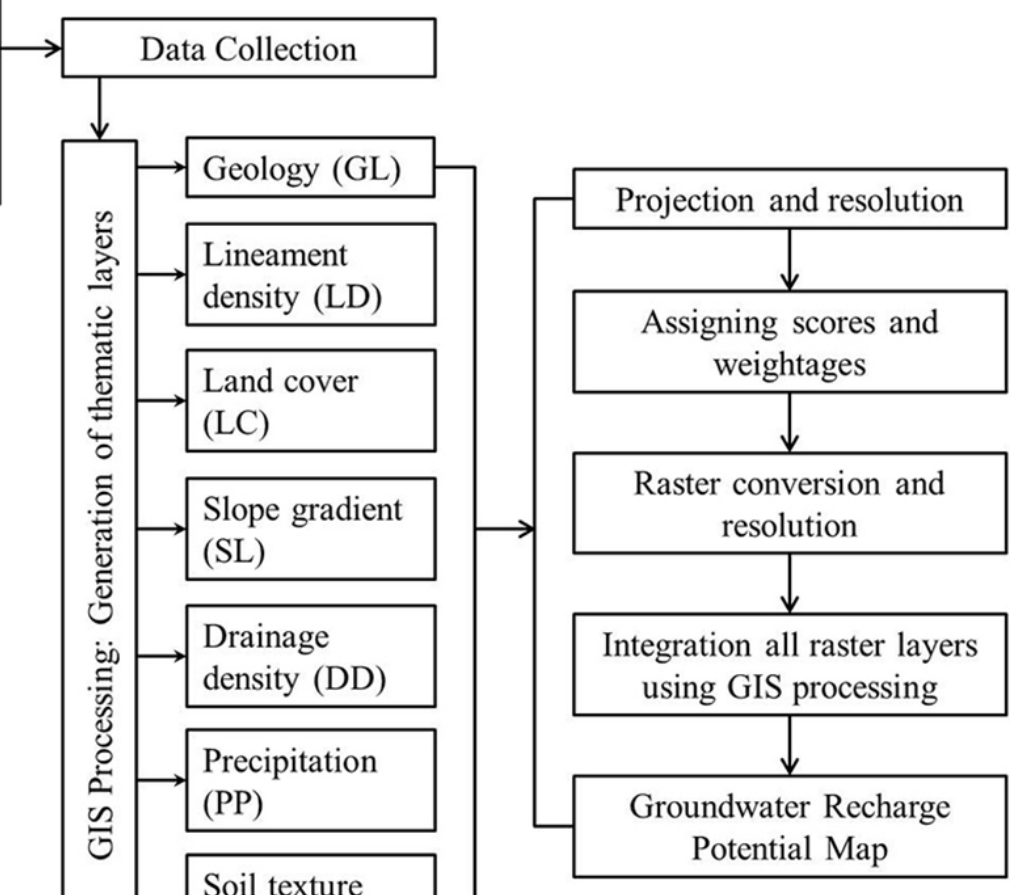

Fig. 4. Flowchart for groundwater potential assessment methodology using GIS techniques. 
In order to delineate the potential groundwater recharge zones of Bulgaria, GIS technology was employed in the study. The identification of suitable sites for groundwater recharge was conducted through a knowledge-based factor analysis, making use of precipitation, lineament-length density, slope gradient, horizontal fragmentation, land cover, lithology, and type of soil layers. For each factor, a thematic map was created. The thematic maps were then converted into a raster graphic format $(1 \times 1 \mathrm{~km})$, which can easily be integrated into a GIS platform. To each of these thematic maps, a suitable weightage factor was assigned, and the factors' influence on the groundwater recharge and the interaction between them was examined.

\section{INTERRELATIONSHIP AND WEIGHTAGE CALCULATION FOR THE FACTORS AFFECTING THE POTENTIAL RECHARGE ZONES}

\section{Multi-influencing factors - interrelationship}

The outlining of potential recharge areas is based on analysis of the most influential factors. In this study, the weights of different factors for the assessment of the potential groundwater recharge and the scoring of various features were assessed based on the characteristics of the study area. The factors influencing the groundwater recharge, and their relative importance, were compiled from the available literature (Yeh et al., 2009; Magesh et al., 2012; Murasingh and Jha, 2013; Gumma and Pavelić, 2013; Venkateswaran et al., 2014; Selvam et al., 2016; Senanayake et al., 2016; Yeh et al., 2016).

Data for all the factors were integrated into a single final map, showing the overall recharge potential of the studied area. An integrated recharge potential map was then produced, showing the areas (actual or potential) with different levels of groundwater recharge. The recharge potential for a given area can be represented as a sum of the specific values for the individual processes, as shown in Fig. 5. It is necessary to take into account the intensity of these processes.

The integration of hydrogeological processes into a single map is an easy process when GIS technology is being used. A more problematic issue can be the weightages that should be assigned to the factors related to the groundwater recharge. Such a task requires some expert assessment to be performed, which can have a significant impact on the resulting integrated potential recharge values.

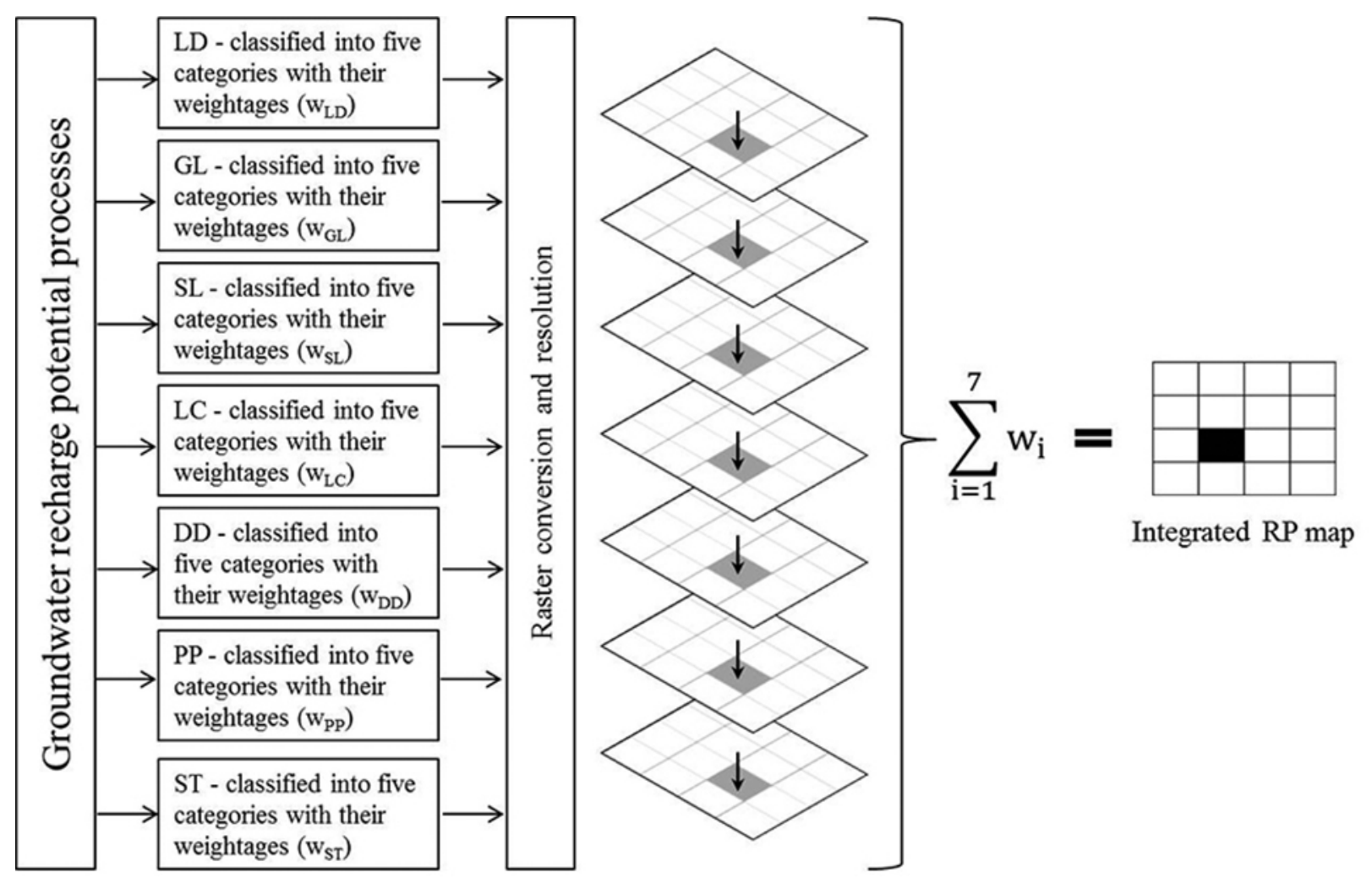

Fig. 5. Calculation processes for the groundwater recharge potential. 
Table 2

Factors influencing the groundwater recharge classified criteria (after Yeh et al., 2009)

\begin{tabular}{ll}
\hline Factor & Basis of categorization \\
\hline Geology & Rock type, terrain permeability \\
Land cover & Type, areal extent \\
Slope & Slope gradient \\
Lineaments & Lineament-length density value \\
Drainage & Drainage-length density value \\
Rainfall & Average value, areal extent \\
Soil & Texture, areal extent \\
\hline
\end{tabular}

The various factors affecting the recharge and their relative importance have already been described in many of the previous studies conducted abroad. The present study analyzed the main factors influencing the process of recharge on the territory of Bulgaria. The basis of their categorization is given in Table 2. The interrelationships between these factors, as well as their effects, are shown in Fig. 6. Each aspect of these relationships has been weighted according to the strength of its impact and described as either primary (major effect) or secondary (minor effect).

\section{Weightage calculation}

The multi-influencing factors for groundwater potential zones, namely the lineament density, horizontal fragmentation, lithology (rock permeability), slope gradient, land cover/use, annual precipitation, and soil texture, were examined and an appropriate weightage was assigned (Table 3). The effect of each influencing factor may contribute to delineating the groundwater potential zones. Moreover, these factors were found to be interdependent. The effect of each major and minor factor (Fig. 6) was assigned a weightage of 1.0 and 0.5 (cf. Yeh et al., 2009). The cumulative weightage of both major and minor effects were considered when calculating the relative rates (Table 3). These rates were further used to calculate the score for each one of the influencing factors. The proposed score for each influencing factor has been calculated by using the following equation:

$$
\text { Score }=100 \times\left(\frac{\mathrm{A}+\mathrm{B}}{\sum_{\mathrm{i}=1}^{7}(\mathrm{~A}+\mathrm{B})}\right)
$$

where: ' $A$ ' is a major interrelationship between two factors, and ' $\mathrm{B}$ ' is a minor interrelationship between two factors.

The concerned score for each influencing factor was divided equally and assigned to each reclassified
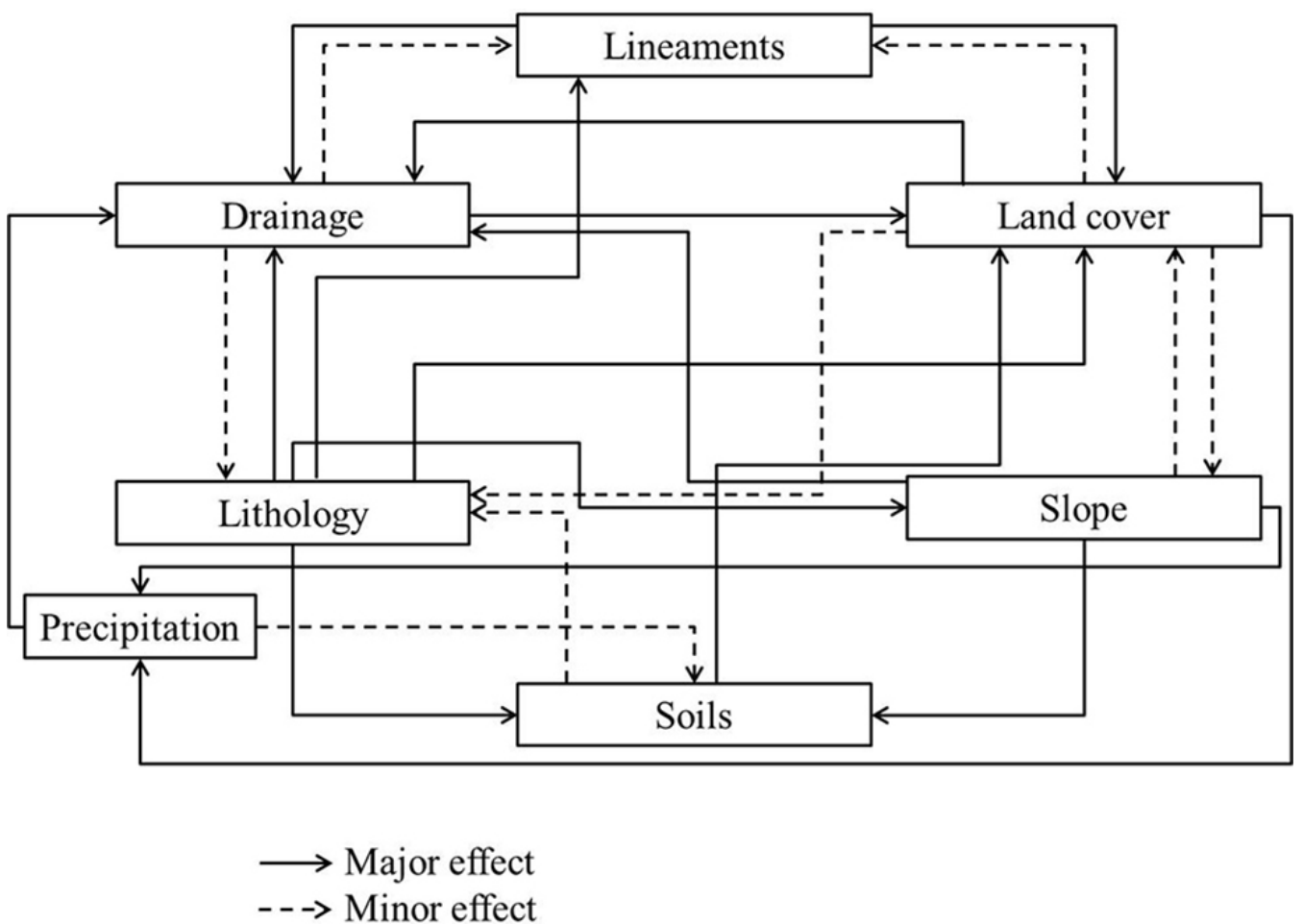

Fig. 6. Interrelationship between the multi-influencing factors concerning the groundwater potential zone. 
Table 3

Effect of influencing factors, their relative rates, and score for each potential factor

\begin{tabular}{lllcc}
\hline Factors & Major effect (A) & Minor effect (B) & Proposed relative rates (A+B) & Proposed score for each factor \\
\hline Lineaments & $1+1$ & 0 & 2.0 & 10 \\
Land cover & $1+1$ & $0.5+0.5+0.5$ & 3.5 & 18 \\
Lithology & $1+1+1+1+1$ & 0 & 5.0 & 25 \\
Drainage & 1 & $0.5+0.5$ & 2.0 & 10 \\
Slope & $1+1+1$ & 0.5 & 3.5 & 18 \\
Precipitation & $1+1$ & 0.5 & 2.5 & 13 \\
Soils & 1 & 0.5 & 1.5 & 8 \\
\hline
\end{tabular}

factor (Table 4). All factors were classified into five categories (domains of effect) along with their weightages, which were assigned according to very good, good, moderate, poor, and very poor recharge zones, i.e., the higher weightages correspond to better recharge, and the lower weightages to worse recharge (Table 4).

Finally, a number of raster maps with the proposed weightages for the individual factors relevant to the recharge potential were created. Then, all raster maps were integrated in order to obtain the groundwater recharge potential index of each pixel in the studied area (Fig. 4). The equation of the groundwater recharge potential model can be presented as follows:

$$
\begin{aligned}
\mathrm{RP} & =\sum_{\mathrm{i}=1}^{7} \mathrm{w}_{\mathrm{i}} \\
\mathrm{w}_{\mathrm{i}} & =\frac{\text { Score }_{\mathrm{i}}}{\mathrm{n}}
\end{aligned}
$$

where: RP is the recharge potential; ' $\mathrm{w}_{\mathrm{i}}$ ' is the proposed weight of effect defined in Table 4; 'Score ${ }_{i}$ ' is the proposed score for each influencing factor, defined by equation (1) and Table 3 ; the subscripts ' $i$ ' refer to the individual features of a theme; ' $n$ ' is domain of effect (in our case, $\mathrm{n}=5$ classes according to Table 4).

\section{RESULTS AND DISCUSSION}

\section{Groundwater recharge potential factors and spatial assessment - weightage calculation}

\section{Geological settings}

The geological and hydrogeological settings, as well as the bedrock composition, are very important for the formation of the recharge zones. Shaban et al. (2006) pointed out that the type of rock exposed on the surface significantly affects the groundwater re-
Table 4

Classification of weighted factors influencing the groundwater

\begin{tabular}{|c|c|c|}
\hline Factors & Domain of effect & $\begin{array}{c}\text { Weight } \\
\text { of effect } \\
\text { (weightage) }\end{array}$ \\
\hline \multirow{5}{*}{$\begin{array}{l}\text { Lineament-length } \\
\text { density, } \mathrm{km} / \mathrm{km}^{2}\end{array}$} & $0-0.5$ & 2.0 \\
\hline & $0.5-1$ & 4.0 \\
\hline & $1-2$ & 6.0 \\
\hline & $2-3$ & 8.0 \\
\hline & $>3$ & 10.0 \\
\hline \multirow[t]{5}{*}{ Land cover } & Artificial surfaces & 3.6 \\
\hline & Water bodies & 7.2 \\
\hline & $\begin{array}{l}\text { Forest and semi- } \\
\text { natural areas }\end{array}$ & 10.8 \\
\hline & Agricultural areas & 14.4 \\
\hline & Wetlands & 18.0 \\
\hline \multirow{5}{*}{$\begin{array}{l}\text { Lithology (terrain } \\
\text { permeability) }\end{array}$} & Very high & 25.0 \\
\hline & High & 20.0 \\
\hline & Moderate & 15.0 \\
\hline & Low & 10.0 \\
\hline & Very low & 5.0 \\
\hline \multirow{5}{*}{$\begin{array}{l}\text { Drainage-length } \\
\text { density, } \mathrm{km} / \mathrm{km}^{2}\end{array}$} & $0-0.5$ & 10.0 \\
\hline & $0.5-1$ & 8.0 \\
\hline & $1-2$ & 6.0 \\
\hline & $2-3$ & 4.0 \\
\hline & $>3$ & 2.0 \\
\hline \multirow{5}{*}{$\begin{array}{l}\text { Slope gradient, } \\
\text { degree }\end{array}$} & $0-4$ & 18.0 \\
\hline & $4-10$ & 14.4 \\
\hline & $10-17$ & 10.8 \\
\hline & $17-26$ & 7.2 \\
\hline & $>26$ & 3.6 \\
\hline \multirow[t]{5}{*}{ Precipitation, mm } & $423-500$ & 2.6 \\
\hline & $500-600$ & 5.2 \\
\hline & $600-700$ & 7.8 \\
\hline & $700-900$ & 10.4 \\
\hline & $>900$ & 13.0 \\
\hline \multirow[t]{5}{*}{ Soil texture } & Very fine & 1.6 \\
\hline & Fine & 3.2 \\
\hline & Medium fine & 4.8 \\
\hline & Medium & 6.4 \\
\hline & Coarse & 8.0 \\
\hline
\end{tabular}
potential zones 
charge. Lithology affects the groundwater recharge by controlling the percolation of water flow (El-Baz and Himida, 1995, seen in Yeh et al., 2009). Although some researchers have ignored this factor by regarding the lineaments and drainage characters as a function of primary and secondary porosity, this study has included lithology in order to reduce the uncertainty when determining the lineaments and drainage.

Despite being a small country not very large in area, Bulgaria is characterized by a complex geological structure. On its territory, rocks of Proterozoic, Paleozoic, Mesozoic, Paleogene, Neogene, and Quaternary ages occur. According to the conditions of their formation, they are magmatic (intrusive, effusive and pyroclastic), sedimentary, and metamorphic (Fig. 2). Alluvium Quaternary sediments cover almost the entire northern part of the country and can be located mostly in the central southern part of the studied area (Fig. 2). Around 25\% of the total area is covered by Mesozoic sedimentary rocks (primarily in the northern part of the country), followed by alluvium and Quaternary sediments (23\%), Neozoic sedimentary rocks (19\%), and Precambrian metamorphic rocks (13\%) (Table 5).

Table 5

Types of rocks on the territory of Bulgaria

\begin{tabular}{|c|c|c|c|}
\hline System & Bedrocks lithology & $\begin{array}{l}\text { Area, } \\
\mathrm{km}^{2}\end{array}$ & $\begin{array}{l}\text { (\%) of } \\
\text { the entire } \\
\text { territory }\end{array}$ \\
\hline Quaternary & Quaternary deposits & 25,998 & 23.4 \\
\hline Neozoic & Sedimentary rocks & 21,301 & 19.2 \\
\hline Neozoic & Intrusive rocks & 440 & 0.4 \\
\hline Neozoic & $\begin{array}{l}\text { Volcanic and volcano- } \\
\text { sedimentary rocks }\end{array}$ & 3,669 & 3.3 \\
\hline Mesozoic & Sedimentary rocks & 27,958 & 25.2 \\
\hline Mesozoic & Intrusive rocks & 2,053 & 1.8 \\
\hline Mesozoic & $\begin{array}{l}\text { Volcanic and volcano- } \\
\text { sedimentary rocks }\end{array}$ & 3,588 & 3.2 \\
\hline Mesozoic & Metamorphic rocks & 1,157 & 1.0 \\
\hline Paleozoic & Sedimentary rocks & 1,383 & 1.2 \\
\hline Paleozoic & Intrusive rocks & 7,373 & 6.6 \\
\hline Paleozoic & $\begin{array}{l}\text { Volcanic and volcano- } \\
\text { sedimentary rocks }\end{array}$ & 334 & 0.3 \\
\hline Paleozoic & Metamorphic rocks & 807 & 0.7 \\
\hline $\begin{array}{l}\text { Pre- } \\
\text { Paleozoic }\end{array}$ & Metamorphic rocks & 14,176 & 12.8 \\
\hline
\end{tabular}

In order to accomplish its goals, the study makes use of data for establishing the approximate permeability of geological formations (Fig. 7). These data were prepared on the basis of the following sources: 1) geological map of Bulgaria 1:500 000 (Cheshitev and Kanchev, 1989); 2) map of hydrogeological elements, important for construction work 1:500 000 (Kamenov et al., 1963b); 3) engineering-geological map of Bulgaria 1:500 000 (Kamenov et al., 1963a); and 4) map of the hydrogeological division of Bulgaria 1:600 000 (Antonov et al., 1960). These maps were used in order to compile the geology layer and to determine the respective weightage. It was found that the lower-laying regions around the downstream are mainly composed of sands, clay sands, gravels, and gravel sands, i.e., sediments displaying inter-granular porosity and high water permeability. Gravels and sands in the lowlands/plains, and open karst areas in the mountainous are excellent regions for water percolation (rainfall infiltration). The suitable weightages for terrain permeability are shown in Table 4. Weightages 5 and 10 were assigned to the fissured, fissured-karst, and fissured-porous types of groundwater collectors. Weightage 15 (the moderate value) was set for the fissured, fissured-karst, fissured-karst-porous, and porous media. Areas of high permeability (weightage 20) refer to highly weathered rocks, fissured-karst, karst-porous, fissured-karst-porous, and porous environments. The very high permeability areas (weightage 25 ) were reserved for karst, porous, and karst-porous environments.

\section{Lineament patterns}

O’Leary et al. (1976) defined lineaments as simple and complex linear geological structures, such as faults, cleavages, fractures, and various surfaces of discontinuity, that are arranged in a straight line or forming a slight curve. According to Subba Rao et al. (2001), lineaments give a clue to movement and storage of groundwater, and therefore can serve as important guides for groundwater exploration.

A high lineament density value infers high secondary porosity, thus indicating a zone with high levels of potential groundwater recharge. The lineaments were obtained from the geological series maps of Bulgaria in scale 1:100 000. From these maps, a raster layer was prepared, showing the lineament-length density (Fig. 8). A lineament-length density map shows, in quantitative terms, the linear features expressed in the form of a grid. The lineament-length density of an area can reveal the groundwater potential areas indirectly, since the presence of lineaments usually denotes a permeable zone and permeability increases as the fracture density increases (Bisson and Lehr, 2004). For the purpose of the present analysis, a lineament map was made and subsequently categorized into five classes. Therefore, the weightage was assigned as high 


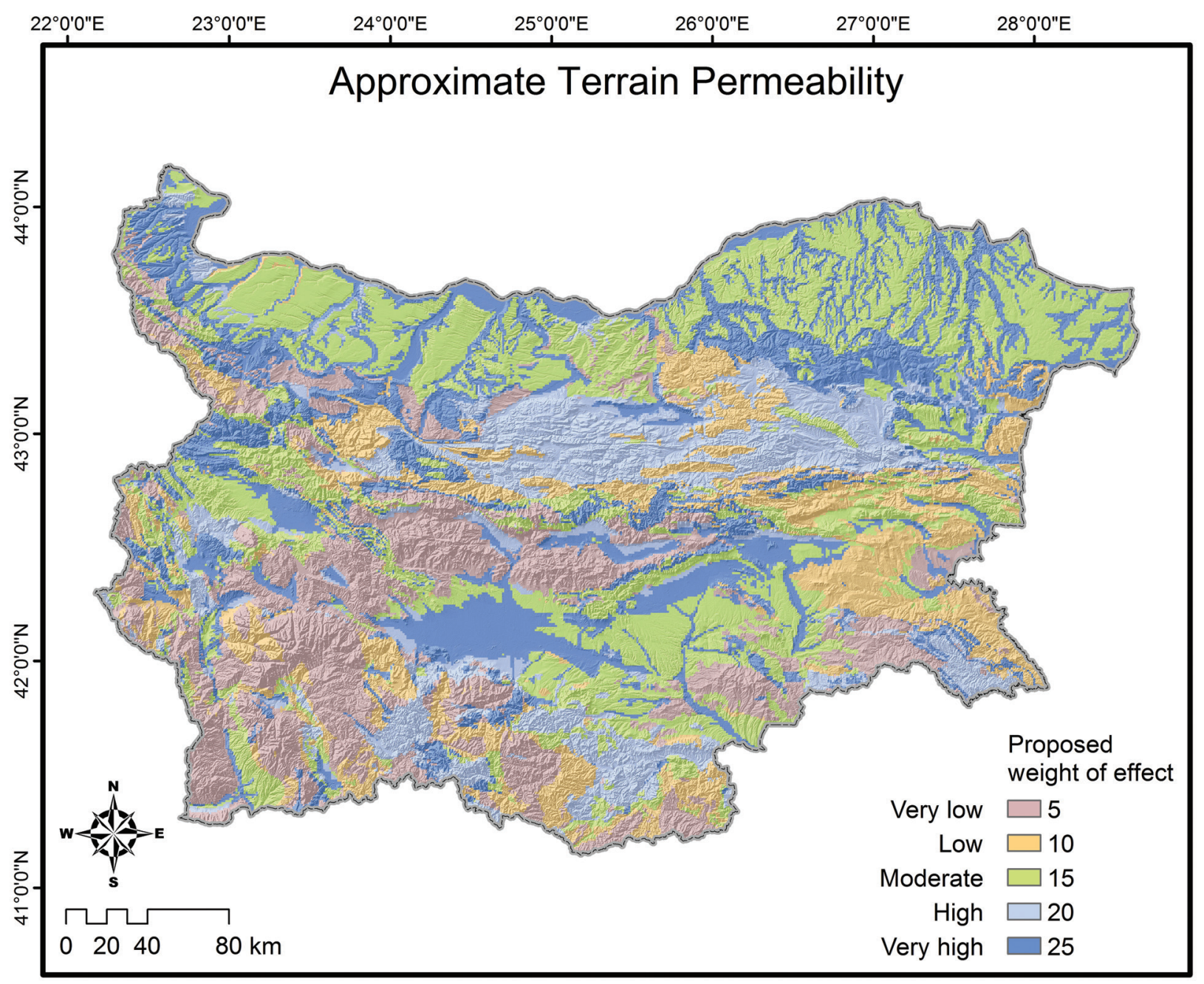

Fig. 7. Adapted map of approximate permeability of the studied terrain showing the assigned weight of effect.

for the higher densities and low for the lower ones (Fig. 8). Suitable weightages for lineament density are shown in Table 4 . The average frequency values fall into the range of $0-6.6 \mathrm{~km} / \mathrm{km}^{2}$ (Fig. 8).

\section{Drainage patterns}

Drainage density is one of the most important characteristics describing the landscape, and it depends on the permeability of the terrain. According to Edet et al. (1998), the drainage pattern is an important indicator of hydrogeological features since, along with texture and density, it is controlled in a fundamental way by the underlying lithology. In addition, the creek pattern is a reflection of the rate with which precipitation infiltrates in comparison with the surface runoff. The relationship between infiltration and runoff is controlled to a large extent by the permeability, which is in turn a function of the rock type and fracturing of the underlying rock or bedrock surface. A drainage-length density map was prepared from drainage-length per square $\mathrm{km}$ (Fig. 9). In addition, a table of suitable weightages for the drainage density was also prepared in due course (Table 4). Hydrographical settings influencing the formation and regime of the discharge affect indirectly the potential groundwater recharge zones.

The river network density in Bulgaria is considerable, and it alternates in the range of $0 \mathrm{~km} / \mathrm{km}^{2}$ to $5.1 \mathrm{~km} / \mathrm{km}^{2}$ (Fig. 9). It is influenced by the variability of terrain, its geologic and tectonic structure, the lithology of rock formations, the land cover, as well as the climatic conditions. The river network density is greater in the mountainous areas, where there is more surface runoff. On the other hand, the density is at its lowest in the Danube Plain, and particularly in the Dobrudzha Region, in the northeast of the country. It is a well-known fact that the denser the drainage network, the smaller the recharge rate, and vice versa. The drainage density map re- 


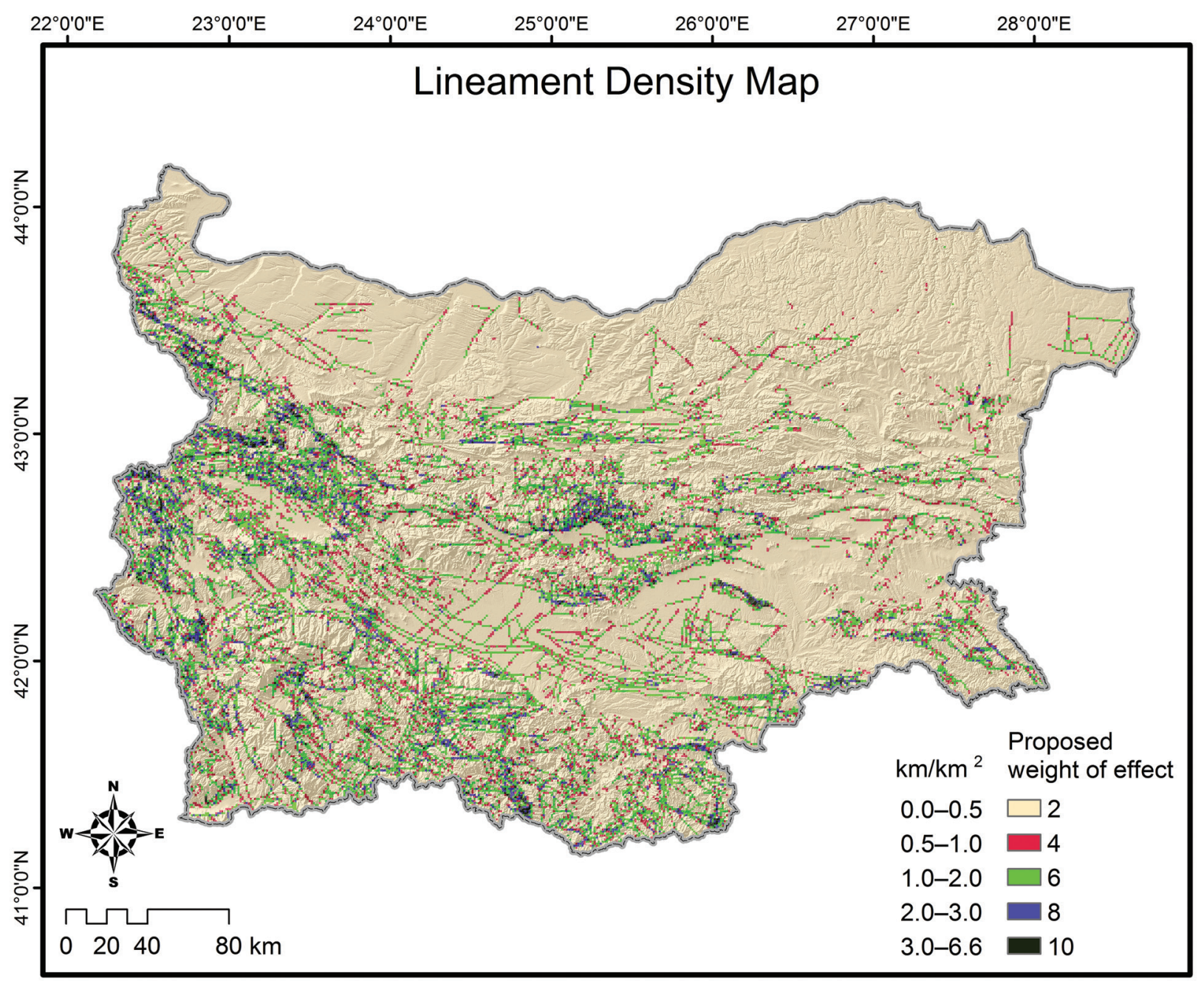

Fig. 8. Lineament-length density map of Bulgaria showing the assigned weight of effect.

veals that density values are regrouped into five categories and range from $3-5.1 \mathrm{~km} / \mathrm{km}^{2}$ (very high), 2-3 km/ $\mathrm{km}^{2}$ (high), 1-2 km/ $\mathrm{km}^{2}$ (moderate), $0.5-1 \mathrm{~km} / \mathrm{km}^{2}$ (low) to $0-0.5 \mathrm{~km} / \mathrm{km}^{2}$ (very low) (Fig. 9). Considered from a recharge point of view, more weightage was assigned to regions of very low drainage-length density, whereas less weightage was assigned to very high densities - areas unsuitable for groundwater development because of the greater surface runoff. The most appropriate weightages for drainage density are shown in Table 4 and Fig. 9.

\section{Land Cover}

The land cover and its usage in the studied area can be characterized as a mixture of forests, pastures, agricultural land, urban areas, and water bodies. Out of 44 classes described in Level 3 of the CORINE Land Cover 2006, in Bulgaria can be observed 36 land features (classes) (Executive Environment Agency of Bulgaria, http://eea.government.bg/bg/ projects/korine-14/osn-inform). For the territory of Bulgaria, most land falls in the following classes: arable lands (51.40\%); forests and semi-natural areas (42.44\%); and anthropogenic objects (4.70\%). For the current task, the classes of land cover from Level 1 were used (Fig. 10). The suitable weightages for the particular type of land cover are shown in Table 4.

\section{Slope Gradient}

The slope of the terrain has a significant role when assessing the potential recharge zones. The steepness of the slope affects the generation of surface runoff, and the infiltration of precipitation. The slope gradient is very important for the formation of soil cover, as well as the land use for any given territory. The various regions in Bulgaria range in their 


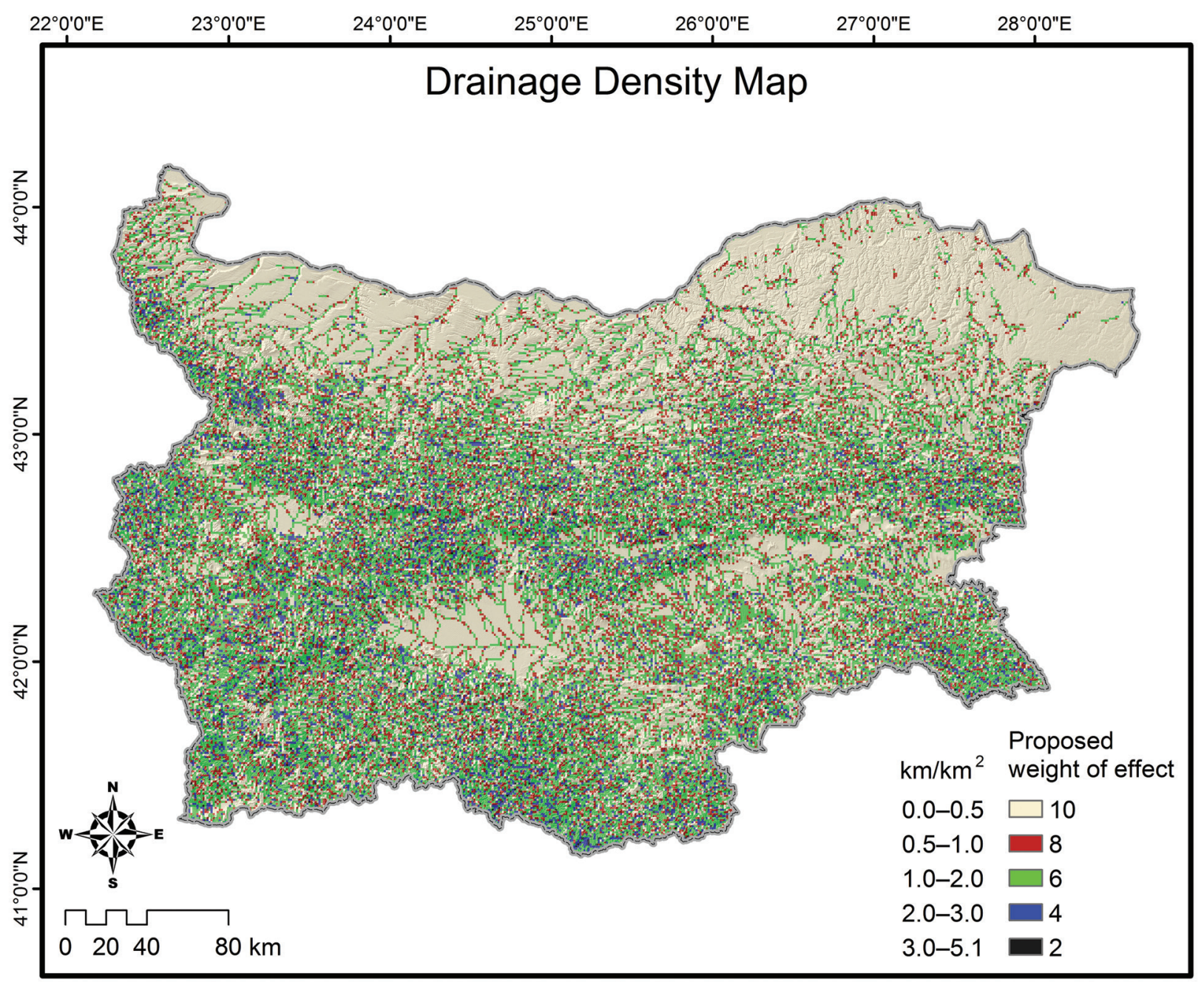

Fig. 9. Drainage-length density map of Bulgaria showing the assigned weight of effect.

steepness from $0-4$ degrees in the plains and valleys, to above 25 degrees in the mountainous areas (Fig. 11). According to data from DEM90, 52\% of the territory of Bulgaria has a slope of 0-4 degrees, and only $3 \%$ are with a slope above 26 degrees (Table 6).

Slope has been classified into five categories (plain, slight, moderate, steep, or very steep), along

Table 6

Steepness of the studied area

\begin{tabular}{lcc}
\hline Slope, deg. & Area, $\mathrm{km}^{2}$ & $\begin{array}{c}(\%) \text { of the entire } \\
\text { territory }\end{array}$ \\
\hline $0-4$ & 57,663 & 52 \\
$4-10$ & 26,041 & 24 \\
$10-17$ & 15,229 & 14 \\
$17-26$ & 9,009 & 8 \\
$>26$ & 2,786 & 3 \\
\hline
\end{tabular}

with their weightages; the weights were assigned according to the slope influence on recharge potential (Fig. 11). A slope of $<4^{\circ}$ is regarded as plain region because low level of the surface runoff usually translates into a very good recharge zone. The areas having a $4^{\circ}-10^{\circ}$ slope are considered as good for groundwater storage due to slightly undulating topography with little overland flow. The areas having a slope of $10^{\circ}-17^{\circ}$ cause relatively moderate runoff, and hence they can be categorized as moderate. Slopes having $17^{\circ}-26^{\circ}$ are mostly considered as poor recharge zones, and areas having a slope $>26^{\circ}$ are considered very poor recharge zones due to their steeper slope and rapid surface runoff. In the process of preparing a map of the potential groundwater recharge zones, the least amount of weightage was assigned to steeper terrains, whereas more weightage was given to gentler slopes, as the slope gradient plays a significant role in infiltration versus runoff. 


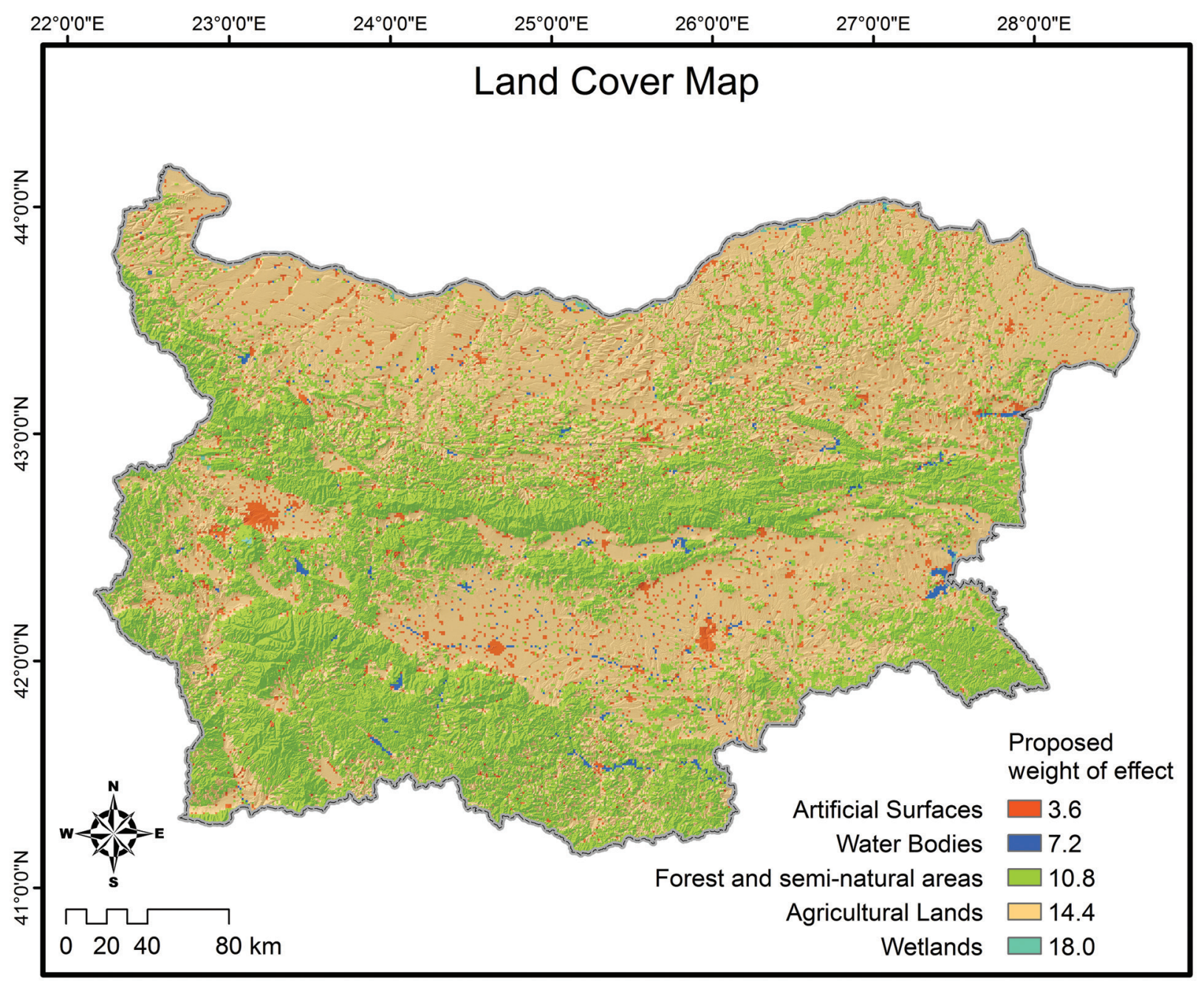

Fig. 10. Land cover map of Bulgaria (CLC 2006) showing the assigned weight of effect.

The suitable weightages for different slope gradients were prepared according to SRTM_90 (http:// srtm.csi.cgiar.org), and the results are shown in Fig. 11 and Table 4.

\section{Precipitation}

One of the main climatic factors affecting the formation of river discharge and recharge potential zones is precipitation, which is unevenly distributed on the territory of Bulgaria. The annual precipitation increases from the northern parts towards the southern parts of the studied area (Fig. 3). The total sum of rainfalls is higher: approximately 1,100$1,400 \mathrm{~mm}$ in the mountainous areas and lower in the middle and low mountain regions (from 800$900 \mathrm{~mm}$ to $1,000-1,200 \mathrm{~mm}$ ); in the hilly regions the precipitation is $700 \mathrm{~mm}$ on average, and in the lowlands, where the main portion of the precipitation evaporates or infiltrates, it is about $600 \mathrm{~mm}$.
An annual precipitation map of the research area (Fig. 12) was prepared using the annual precipitation measured at the meteorology stations for the period 1931-1985 (Koleva and Peneva, 1990) and the surrounding area. Grid cells $(1 \times 1 \mathrm{~km})$ were created on this map. Suitable weightages for annual mean areal extent precipitation is shown in Table 4.

\section{Soils}

Soils in Bulgaria are very diverse in origin and composition, and soil cover has a complex spatial structure (Ninov, 2002). In the lowlands, plains and hills of the country, most widely spread are the chernozems $(\mathrm{CH})$, luvisols $(\mathrm{LV})$, followed by vertisols (VR), phaeozems (PH), planosols (PL), and leptosols (LP). In this belt, solonetz (SN) and solonchaks (SC), some fluviosols (FL), and other type of soils can also be found. Most limited in this zone are the cinnamonic soils, alisols (AL), and regosols (RG). 


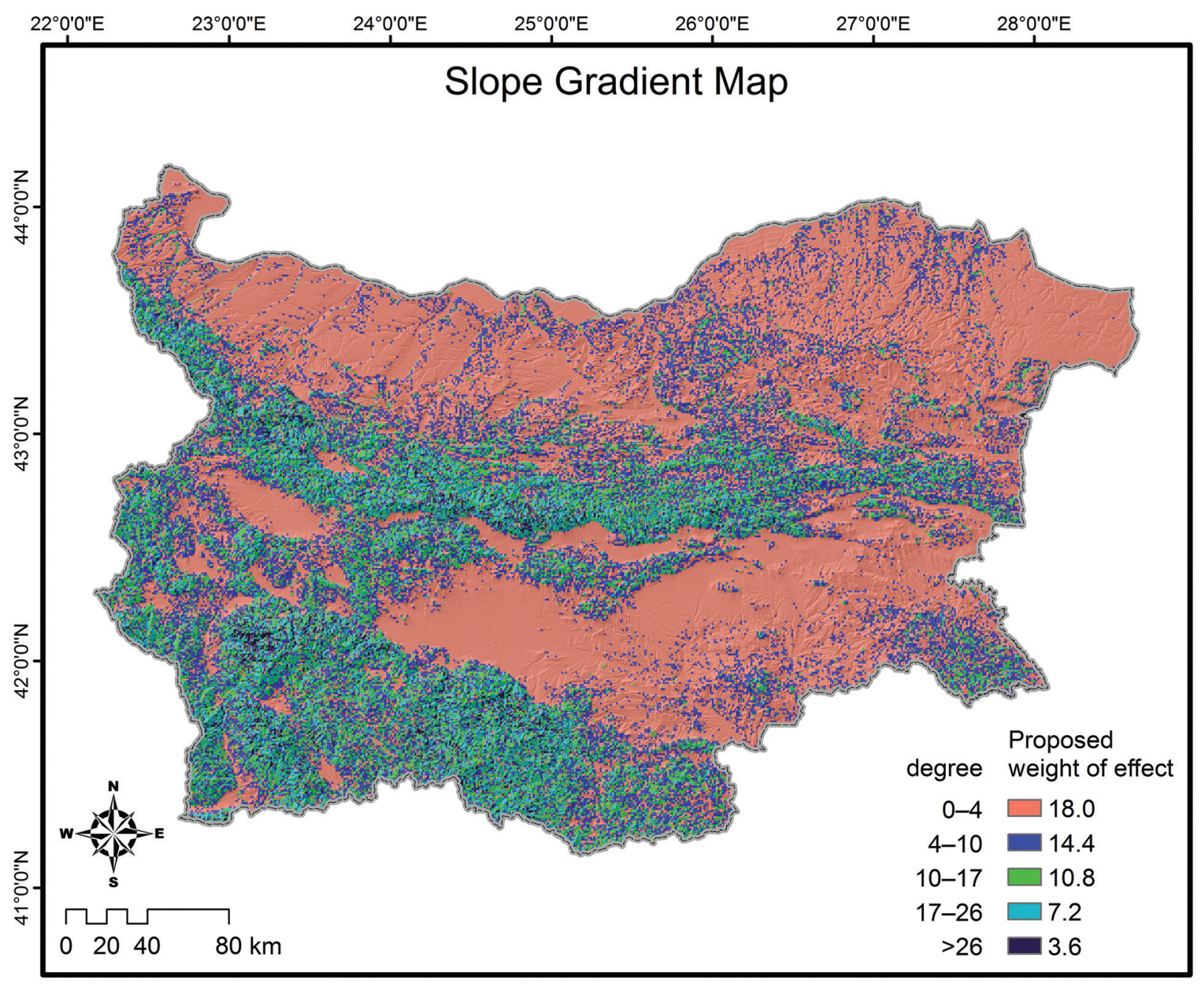

Fig. 11. Slope-gradient map of the study area showing the assigned weight of effect.

The mountainous areas of Bulgaria are characterized by the widespread occurrence of cambisols (CM).

Diffuse groundwater recharge is the amount of water that infiltrates through the soil cover and reaches its level. Therefore, when determining the potential groundwater recharge zones, it is important to have data on the soil texture on which both the field capacity and infiltration of rainwater depend. Water content of soils depends on their grainsize composition. Soils with coarse texture have higher water permeability, whereas soils with fine and very fine texture have the lowest permeability. Most of the country is covered by soils with medium-fine texture. Soils with fine texture can be found in north-eastern Bulgaria, and soils with medium texture in the south-western parts and some areas in northern Bulgaria. Soils having very fine texture are characteristic of the south-eastern regions (Fig. 13). Clayish soils have greater water-holding capacity than sandy soils. Soils with greater available water capacity (AWC) have higher water-holding capacity, and they were assigned lower weightages accordingly. These soil types are located in the south-eastern and western regions of the studied area. Soils with poor water-holding capacity were given higher weightages. Such soil types are located in small regions in the western, some central, northern and south-western parts of the study area. The suitable weightages for the various types of soils are shown in Table 4.

\section{Demarcation of the groundwater recharge zones}

At the final stage, a map was drawn up, showing the potential groundwater recharge zones (Fig. 14) within the study area. The indicators of groundwater occurrence and recharge are related to rainfall distribution, land cover, geology, slope, soil, and 


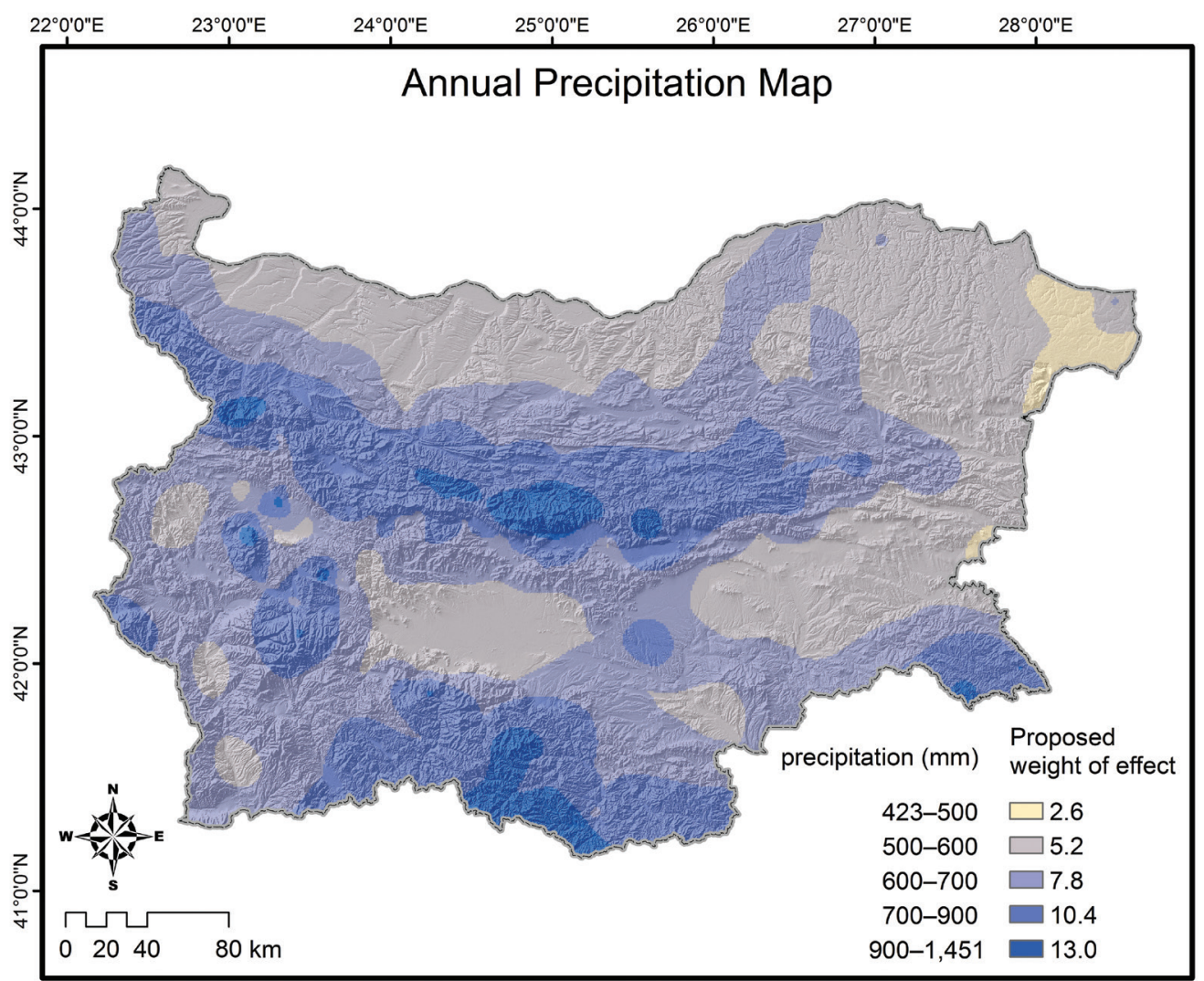

Fig. 12. A long-term mean annual precipitation map of Bulgaria showing the assigned weight of effect.

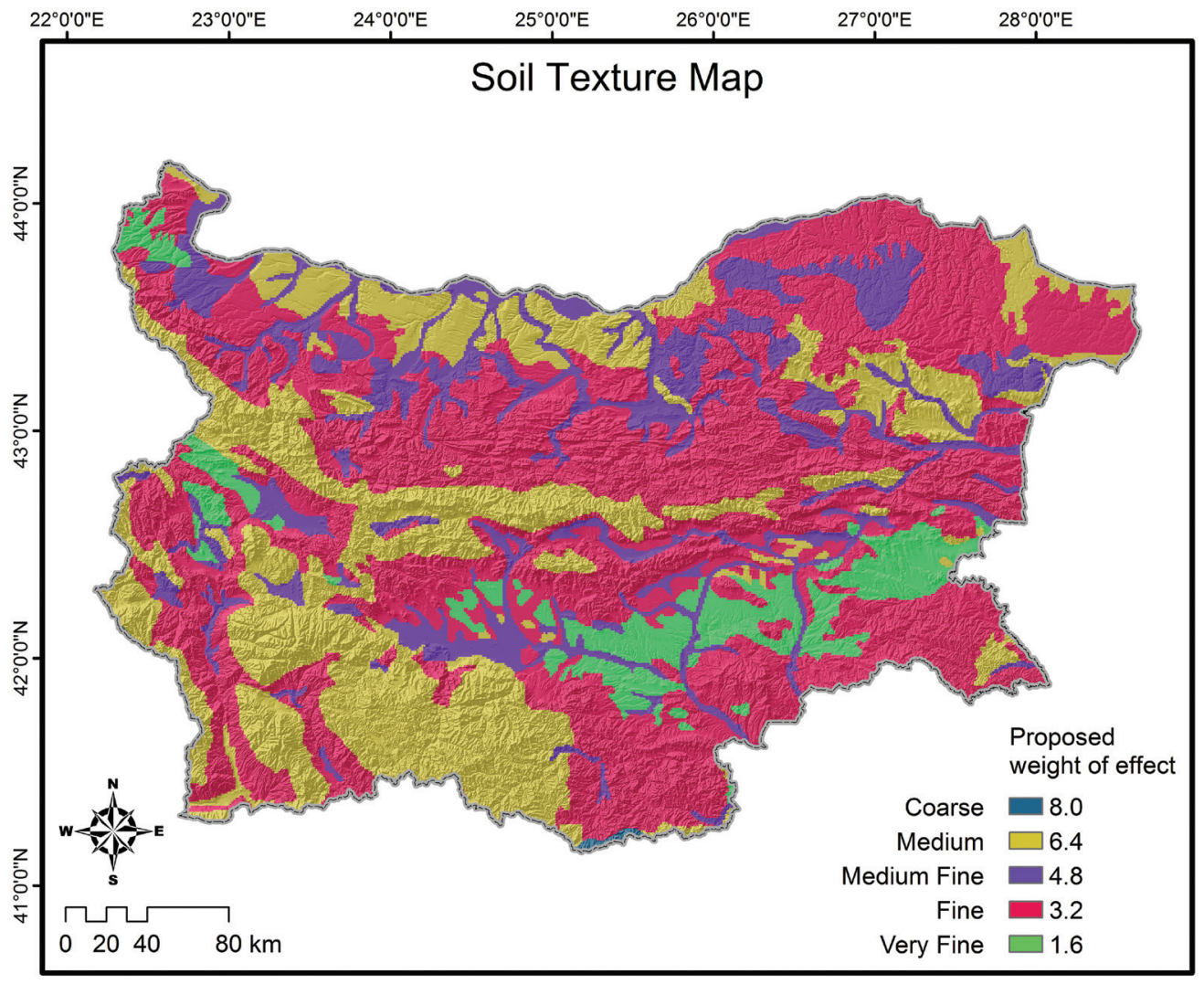

Fig. 13. Soil texture map of Bulgaria showing the assigned weight of effect. 


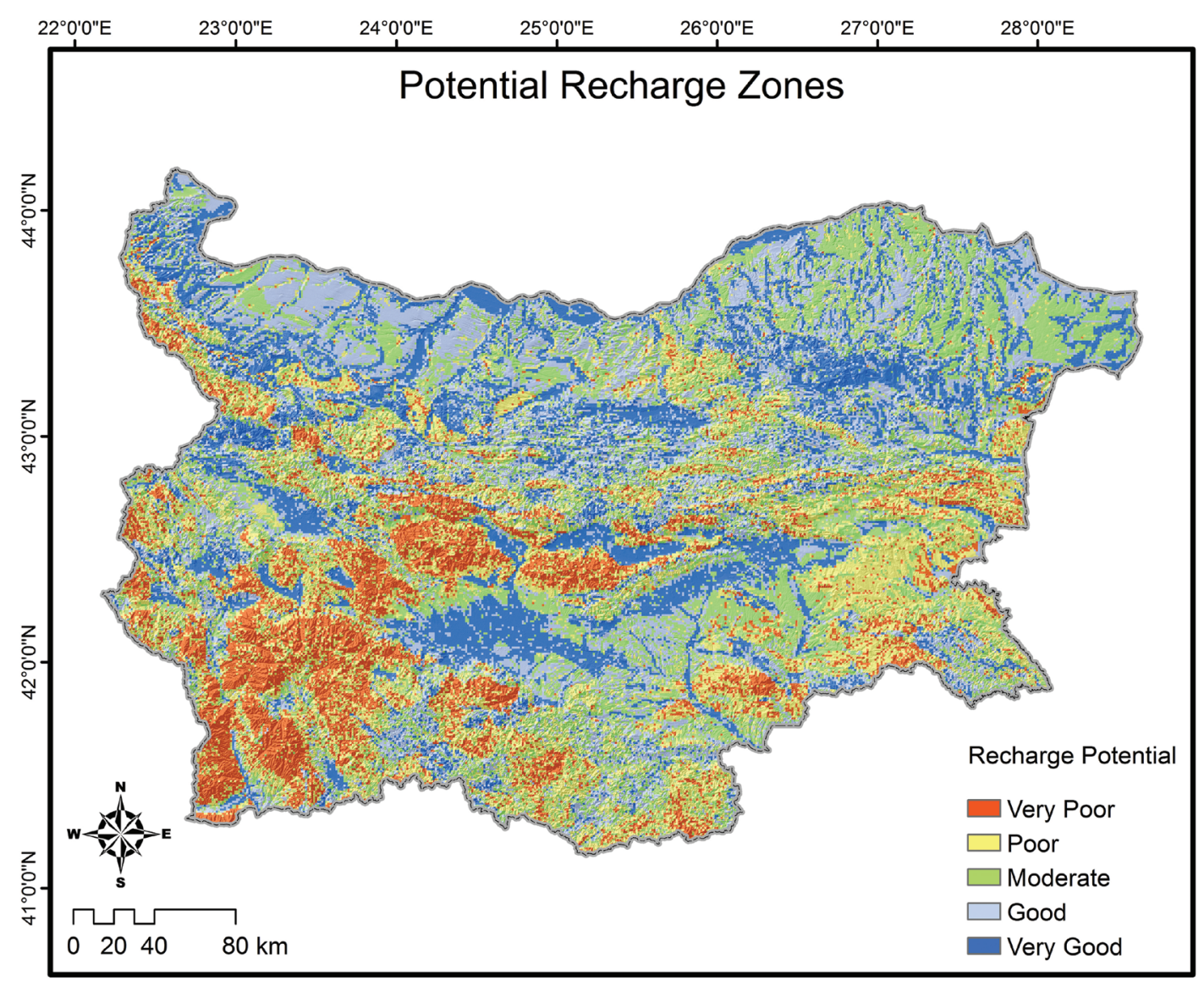

Fig. 14. Groundwater recharge potential zones of Bulgaria.

Table 7

Reclassification of potential recharge zones generated during the integration of thematic layers

\begin{tabular}{lcc}
\hline Recharge Potential & Area, $\mathrm{km}^{2}$ & $\begin{array}{c}\text { (\%) of the entire } \\
\text { territory }\end{array}$ \\
\hline Very poor & 13,414 & 12 \\
Poor & 23,341 & 21 \\
Moderate & 27,726 & 25 \\
Good & 25,772 & 23 \\
Very good & 20,495 & 19 \\
\hline
\end{tabular}

drainage features of the area. In order to predict the groundwater recharge potential zones, different thematic maps were prepared. These include annual mean precipitation distribution, land cover, geology (rocks' permeability), lineament-length density, soil texture, slope gradient, and drainage-length density (see Figs 7-13). Integrated assessment of thematic maps, using a model based on GIS techniques, was a suitable method for predicting groundwater potential. The compiled map (Fig. 14) shows that, in large areas of the territory of Bulgaria (33\%), the re- charge potential is poor to very poor (Table 7), 23\% of the area has good recharge potential, $25 \%$ of the area has moderate groundwater recharge potentiality, and the remaining area (19\%) has a very good groundwater recharge potential.

\section{CONCLUSION}

The delineation of the groundwater recharge potential zones in the Bulgarian countryside was conducted making use of GIS technology that provided an effective methodology in the context of time, labor and cost. Seven parameters, such as the annual precipitation, lineament density, slope gradient, drainage density, land cover, lithology, and soil texture layers, were integrated on a GIS-platform employing the weighted linear combination method. The data presented in the article were analyzed and processed in GIS environment, and for each factor a raster map with $1 \times 1 \mathrm{~km}$ grid was generated. Also, for each of the factors, influencing the groundwater recharge, the weightage was assigned in a spatial domain. 
In this study, seven thematic layers have been generated for the analysis and integration into a groundwater recharge prospect map.

The resulting final map shows that $67 \%$ of the area has very good to moderate recharge potential, mainly confined to agricultural land use and river terraces (where a considerable amount of precipitated water percolates into the subsurface), $21 \%$ of the area has a poor groundwater recharge potential, and the remaining area $(12 \%)$ has a very poor recharge potential. The residual hills and linear ridges with steep slopes have been found to be unsuitable for recharge sites.
An integrated map showing the potential groundwater recharge zones has been prepared on the basis of available free data (resources). The main concept of the present research might be used for a more elaborate investigation of the problem. From the final map, it can be concluded that, for large areas of Bulgarian territory, the recharge can be described as insignificant, i.e., very poor to poor (33\%). The resultant suitability map and the methodology employed in the study can serve as guiding principles for future water management projects.

\section{REFERENCES}

Antonov, H., Boyadjiev, N., Danchev, D., Iliev, I., Petrov, P., Plotnikov, N. 1960. Map of the hydrogeological division of Bulgaria 1:600 000. Travaux sur la Géologie de Bulgarie, Série Géologie et Hydrogéologie 1, 212 pp. (in Bulgarian).

Bisson, R.A., Lehr, J.H. 2004. Modern groundwater exploration. John Wiley and Sons Inc., New Jersey, 321 pp.

Chenini, I., Mammou, A.B., May, M.E. 2010. Groundwater recharge zone mapping using GIS-based multi-criteria analysis: a case study in Central Tunisia (Maknassy basin). Water Resources Management 24, 921-939.

Cheshitev, G., Kanchev, I. (Eds). 1989. Geological map of Bulgaria 1:500 000. Compiled by Cheshitev, G., Kanchev, I., Valkov, V., Marinova, R., Shilyafova, Y,. Russeva, M., Iliev K. Committee on Geology of Bulgaria, Company for Geophysical surveys and Geological mapping, Sofia.

Edet, A.E., Okereke, C.S., Teme, S.C., Esu, E.O. 1998. Application of remote-sensing data to groundwater exploration: A case study of the Cross River State, southeastern Nigeria. Hydrogeology Journal 6, 394-404.

El-Baz, F., Himida, I. (1992-1995). Research project: Groundwater potential of the Sinai Peninsula, Egypt.

ESDB ver2, 2004. The European Soil Database distribution version 2.0, European Commission and the European Soil Bureau Network, CD-ROM, EUR 19945 EN.

Gumma, M.K., Pavelić, P. 2013. Mapping of groundwater potential zones across Ghana using remote sensing, geographic information systems, and spatial modelling. Environmental Monitoring Assessment 185 (4), 3561-3579.

Jaiswal, R.K., Mukherjee, S., Krishnamurthy, J., Saxena, R. 2003. Role of remote sensing and GIS techniques for generation of ground-water prospect zones towards rural developmental approach. International Journal of Remote Sensing 24, 993-1008.

Japan International Cooperation Agency (JICA) (2006-2008). Project: The Study on Integrated Water Management in the Republic of Bulgaria, GIS Database.

Kadam, A., Sankhua, R.N., Umrikar, B.N. 2015. Assessment of groundwater potential Zones using GIS technique: a case study of Shivganga River basin, Pune, Maharashtra, India. Conference Paper ID: TS1-03. Sixth International Groundwater Conference (IGWC-2015), Chennai, India, 70-77.

Kamenov, B., Iliev, I., Galabov, M., Avramova, E., Stancheva, Tz. 1963a. Engineering geological map of Bulgaria
1:500 000. Geological Institute, Bulgarian Academy of Sciences, Sofia.

Kamenov, B., Iliev, I., Galabov, M., Avramova, E., Stancheva, Tz. 1963b. Map of hydrogeological elements, important for construction work. Appendix 2. Engineering geological map of Bulgaria 1:500 000. Geological Institute, Bulgarian Academy of Sciences, Sofia.

Koleva, E., Peneva, R. 1990. Climate Guide. Precipitation in Bulgaria. Bulgarian Academy of Sciences, Sofia, 169 pp. (in Bulgarian).

Krishnamurthy J., Kumar, N.V., Jayaraman, V., Manivel, M. 1996. An approach to demarcate ground water potential zones through remote sensing and a geographical information system. International Journal of Remote Sensing 17, 1867-1884.

Kyuchukova, M. 1983. Climate Guide of the Republic of Bulgaria. Volume 3. Temperature of the Air, Temperature of the Soil, Frost. Bulgarian Academy of Sciences, Sofia, 440 pp. (in Bulgarian).

Magesh, N.S., Chandrasekar, N., Soundranayagam, J.P. 2012. Delineation of groundwater potential zones in Theni district, Tamil Nadu, using remote sensing, GIS and MIF techniques. Geoscience Frontiers 3 (2), 189-196.

Minkov, M. 1968. Loess in Northern Bulgaria. Complex Investigation. Publishing House of the Bulgarian Academy of Sciences, Sofia, 202 pp. (in Bulgarian).

Murasingh, S., Jha, R. 2013. Identification of groundwater potential zones using Remote Sensing and GIS in a mine area of Odisha. National Conference on "Recent Approaches to Water Resource Management”, Indian School of Mines, Dhanbad, Conference Paper, https://doi.org/ 10.13140/ RG.2.1.4247.7283.

Ninov, N. 1997. Soils. In: Kopralev, I. (Ed.). Geography of Bulgaria. "Prof. Marin Drinov" Publishing House, Sofia, 225-259 (in Bulgarian).

Ninov, N. 2002. Section 4. Soils. In: Kopralev, I., Yordanova, M., Mladenov, Ch. (Eds). Geography of Bulgaria. ForKom Publishing House, Sofia, 277-316 (in Bulgarian).

O’Leary, D.W, Friedman, J.D, Poh, H.A. 1976. Lineaments, linear, lineations: some standards for old terms. Geological Society of America Bulletin 87, 1463-1469.

Saraf, A.K, Choudhury, P.R. 1998. Integrated remote sensing and GIS for groundwater exploration and identification of 
artificial recharge sites. International Journal of Remote Sensing 19, 1825-1841.

Selvam, S., Dar, F.A., Magesh, N.S., Singaraja, C., Venkatramanan, S., Chung, S.Y. 2016. Application of remote sensing and GIS for delineating groundwater recharge potential zones of Kovilpatti Municipality, Tamil Nadu using IF technique. Earth Science Informatics 9 (2) 137-150.

Senanayake, I.P., Dissanayake, D.M.D.O.K., Mayadunna, B.B., Weerasekera, W.L. 2016. An approach to delineate groundwater recharge potential sites in Ambalantota, Sri Lanka using GIS techniques. Geoscience Frontiers 7 (1), 115-124.

Sener, E., Davraz, A., Ozcelik, M. 2005. An integration of GIS and remote sensing in groundwater investigations: a case study in Burdur, Turkey. Hydrogeology Journal 13, 826-834.

Shaban, A., Khawlie, M., Abdallah, C. 2006. Use of remote sensing and GIS to determine recharge potential zones: the case of Occidental Lebanon. Hydrogeology Journal 14, 433-443.
Shahid, S., Nath, S.K., Roy, J. 2000. Groundwater potential modelling in a soft rock area using a GIS. International Journal of Remote Sensing 21, 1919-1924.

Subba Rao, N., Chakradhar, G.K.J., Srinivas, V. 2001. Identification of groundwater potential zones using remote sensing techniques in and around Guntur Town, Andhra Pradesh, India. Journal of the Indian Society of Remote Sensing 29 (1-2), 69-78.

Venkateswaran, S., Pragatheeswaran, P., Manimozhi, C. 2014. Delineation of groundwater potential zones in the upper tirumanimuttar sub basin using remote sensing and GIS techniques. International Journal of Recent Scientific Research 5 (8), 1498-1502.

Yeh, H.-F., Lee, Ch.-H., Hsu, K.-Ch., Chang, P.-H. 2009. GIS for the assessment of the groundwater recharge potential zone. Environmental Geology 58, 185-195

Yeh, H.-F., Cheng, Y.-S., Lin, H.-I., Lee, Ch.-H. 2016. Mapping groundwater recharge potential zone using a GIS approach in Hualian River, Taiwan. Sustainable Environment Research 26, 33-43. 